ADDIN, Volume 11, Number 2, August 2017

\title{
THE INFORMATION STRUCTURE IN ARABIC-JAVANESE TRANSLATION: Case Study In The Book Of Bidayah Al-Hidayah
}

\section{Muhammad Yunus Anis}

Universitas Sebelas Maret Surakarta, Central Java, Indonesia yunus_678@staff.uns.ac.id

\section{Eva Farhah}

Universitas Sebelas Maret Surakarta, Central Java, Indonesia evafarhah@staff.uns.ac.id

\section{Afnan Arummi}

Universitas Sebelas Maret Surakarta, Central Java, Indonesia afnanarummy85@gmail.com

\section{Abstract}

Communication involves the actual use of language in real. As we have known that language is the main medium for communication. One of the important thing to develop the effective communication is by packaging the structure of information. There are two basic elements in the information, they are: theme and rheme. Theme had been considered as the known information and the rheme absolutely had been considered as new information. This paradigm based on the Systemic Functional Linguistics (SFL). Halliday considers language as having three main functions: (1) the ideational function; 
(2) the interpersonal function; and (3) the textual function. This paper will focus in the textual function and "clause as a message". Arabic language has a unique structure of clauses, we can find two basic notions (mubtada'+khabar) and (fi'l+fa'il), in the other hand, semantically, we can find (musnad+musnad ilaib), so this article tried to find the correlation between the structure of Arabic clauses with (theme+rheme) construction. This article also will find out the kinds of theme in Arabic language (multiple themes, clause as themes, and predicated themes). Theme as an initial element in SFL should be described by looking the rheme in the text. The method in this research was divided into three parts: (1) collecting the data from the book of Modern Written Arabic and also some articles in the Arabic-Javanese translation book Bidayah al-Hidayah, the data is the clauses with nominal and verbal initial; (2) analysis data, using the descriptive analysis and distributional method; and (3) reporting the data (formal and informal). The result of this article had concluded that there is a near connection between (mubtada'+khabar), (fil+fa'il), and (musnad+musnad ilaib) with the theme and rheme construction based on the SFL theory.

Keywords: Modern Written Arabic, Clauses, Theme and Rheme, Systemic Functional Linguistics (SFL).

\section{Abstrak}

STRUKTUR INFORMASI TERJEMAHAN BAHASA ARAB-BAHASA JAWA: STUDI KASUS DALAM KITAB BIDAYAH AL-HIDAYAH. Komunikasi meliputi penggunaan bahasa secara nyata. Seperti yang telah kita ketahui bahwa bahasa adalah media utama untuk komunikasi. Salah satu halpenting untuk mengembangkan komunikasi yang efektif adalah dengan mengemas struktur informasi. Ada dua elemen dasar dalam informasi, yaitu: theme dan rheme. Theme dianggap sebagai informasi yang sudah diketahui dan rheme dianggap sebagai informasi baru. Paradigma ini didasarkan pada Systemic Functional Linguistics (SFL). Halliday menganggap bahasa memiliki tiga fungsi utama: (1) fungsi ideasional; 
(2) fungsi interpersonal; dan (3) fungsi tekstual. Penelitian ini fokus pada fungsi tekstual dan "klausa sebagai pesan". Bahasa Arab memiliki struktur klausa yang unik, kita dapat menemukan dua pengertian dasar (mubtada'+khabar) dan (f'l+fa'il). Di sisi lain, secara semantis, kita dapat menemukan (musnad+musnad ilaib). Jadi, artikel ini mencoba menemukan korelasi antara struktur klausa bahasa Arab dengan konstruksinya (theme+rheme). Artikel ini juga membahas jenis tema dalam bahasa Arab (multiple themes, clause as themes, dan predicated themes). Theme sebagai elemen awal dalam SFL harus dijelaskan dengan melibat rheme dalam teks. Metode dalam penelitian ini dibagi menjadi tiga bagian, yaitu: (1) mengumpulkan data dari buku Bahasa Arab Modern dan juga beberapa artikel dalam buku terjemahan Arab-Jawa Bidayah alHidayah, datanya adalah klausa yang dimulai dengan nomina dan klausa yang dimulai dengan verba; (2) analisis data, menggunakan metode analisis deskriptif dan metode distribusi (bagi unsur langsung atau metode Agib); dan (3) pelaporan data (formal dan informal). Hasil dari artikel ini menunjukean babwa ada bubungan yang dekat antara (mubtada'+khabar), (fil+fa'il), dan (musnad+musnad ilaih) dengan theme dan konstruksi rbeme berdasarkan teori SFL.

Kata Kunci: Bahasa Arab, Klausa, Theme dan Rheme, Systemic Functional Linguistics (SFL).

\section{A. Introduction}

This research will elaborate the construction of theme and rheme in Arabic Javanese translation. Theme had been defined as the known information and rheme had been defined as new information. There was a similarity between this construction (theme + rheme) and the construction of (mubtada' + khabar) and (fi'l + fā'il) in Arabic language. Beeston (1968) had defined about the thematic sentence structure as: one in which, in principle, the theme of the statement occupies the initial position after any introductory functional; in some cases, however, this position may be occupied by some other element in the sentence (such 
as prepositional phrase) provided that this is not a verb. Versteegh has concluded that theme and rheme essentially refer to the two elements that make up an ordinary sentence with a binary structure; the "theme" expresses old, familiar information, while the "rheme" expresses new information (focus). Versteegh also emphasized that in Anglophone linguistics (Arabic language), the equivalents are sometimes considered to be "topic/comment" (most often), or "theme/ predicate". Differently from Beeston and Versteegh, Baker (2011) has concluded that the thematic structure of the Arabic translation of this extract deviates from the original for a number of reason, they are:

1. Arabic rarely uses independent pronouns because Arabic verbs are inflected for person, number, and gender. This means that any combination of pronoun plus verb, such as I took or I saw, is rendered by an inflected verb as theme in Arabic;

2. Arabic negative particles come in front of the verb, so that an expression such as I had nothing against becomes literally "not was for me any objection", thus pushing the "me" further away from thematic position;

3. Arabic does not have an equivalent of the present perfect: I've been a director is rendered into Arabic as "since then become I", thus putting a temporal adjunct in theme position and pushing the inflected verb further towards the rheme. ${ }^{1}$

Sentence (الجملة) in Arabic language is a combination of two or more words rendering a useful meaning; the pillar of this sentence is constituted by the information and the subject while any word added to them is called the supplement. There are two kinds of sentences in Arabic language:

${ }^{1}$ Kees Versteegh (ed.), Encyclopedia of Arabic Language and Linguistics, (Leiden: Brill, 2006), Volume V, 484. 
1. The nominal sentence (الجملة الاسميّة) starts basically with a noun; its pillar is constituted by a primate (مبتدة) and a predicate (خبر);

2. The verbal sentence (الجملة الفعليّة) starts basically with a verb; its pillar is constituted by a verb (فعل) and an agent (ناعل) or a pro-agent (نائب الفاعل).

Functional Sentence Perspective (منظور الجملة الوظيفيّ) is a type of linguistic analysis associated with the Prague School which describes how information is distributed in sentences. FSP deals particularly with the effect of the distribution of known (or given) information and new information in discourse. The known information (known as theme, in FSP), refers to information that is not new to the reader or listener. The rheme refers to information that is new. ${ }^{3}$ FSP differs from the traditional grammatical analysis of sentences because the distinction between subject-predicate is not always the same as the theme-rheme contrast. For example we may compare the two sentences below:

(1)

\begin{tabular}{cl}
\hline John & Yajlisu 'ala al-kursiy (Arabic) \\
\hline John & Sat on the seat (English) \\
\hline Subject & Predicate \\
\hline Mubtada' & Khabar \\
\hline Theme & Rheme \\
\hline
\end{tabular}

(2)

\begin{tabular}{cc}
\hline Alal-kursiy jalasa & John \\
\hline On the seat sat & John \\
\hline Predicate & Subject \\
\hline
\end{tabular}

${ }^{2}$ Mona Baker, In Other Words: A Coursebook on Translation Second Edition (London: Routledge Taylor and Francis Group, 2011), 138.

${ }^{3}$ Antoine El-Dahdah, A Dictionary of Universal Arabic Grammar (ArabicEnglish) (Beirut: Librairie du Liban Publishers, 1992), 2. 


\begin{tabular}{cc}
\hline Fill & Fa'il \\
\hline Theme & Rheme \\
\hline
\end{tabular}

John is the grammatical subject in both sentences, but theme in: (1) and rheme in (2). Other terms used to refer to the theme-theme distinction are (topic-comment), (background-focus), (given-new information). The theme in Arabic is a noun (phrase) that has been extraposed, or moved from its original position in the sentence, placed sentence-initially, is given the nominative status (حالة الرفع), has an anaphoric reference (ضمير رابط) in the theme part of the sentence, and that the anaphora refers back to the extraposed theme and agrees with it in number and gender.

The theme is referred to as (المحدّث عند - the person/ thing being talked about) or (مخبر عنه - someone/something being informed about). In terms of information structure, the theme usually represents known (old) information to the addressee while the theme constitutes unknown (new) information to the addressee. Therefore, Arab grammarians have defined it as (هو المعلوم أم المعروف عند المخاطب - it is someone/something known to the addressee). ${ }^{4}$

It is also worthwhile to mention here that this category of Arabic syntactic structure is referred to as "derived order" sentences whose sentence-initial noun (phrase) is labelled as the "theme" and is an extraposed constituent. It is through the grammatical process of extraposition that the theme occurs sentence-initially and is allowed to assume the nominative case marking regardless of the original case marking which reflects its original grammatical status. This category of Arabic constructions is triggered by discourse

${ }^{4}$ Jack C. Richards and Richard Schmidt, Longman Dictionary of Language Teaching and Applied Linguistics (London: Longman Group, 2002), 282. 
phenomena, and the re-ordering, different word orders, of the sentence constituents take place for rhetorical purposes such as emphasis and thematisation.

Within that configuration, the theme is the startingpoint for the message; it is the ground from which the clause is taking off. So part of the meaning of any clause lies in which element is chosen as its Theme. There is a difference in meaning between a balf penny is the smallest English coin, where a half penny is theme (I'll tell you about a halfpenny), and the smallest English coin is a halfpenny, where the smallest English coin is theme (I'll tell you about the smallest English coin). The difference may be characterized as "thematic"; the two clauses differ in their choice of theme. By glossing them in this way, as "I'll tell you about ....", we can feel that they are two different messages.

Rheme of a sentence is the core (focus) of an utterance from the point of view of functional sentence perspective. Rheme in the headline with verbal predicate can be formed by jumlah filiyyah and the rheme in the headline with nonverbal predicate can be formed by particle (حرف) and adverb (ظرف), and also by the construction of syibh al-jumlah. This construction consists of two patterns, they are: (1) jar majrur, and (2) zharart mazhruf.

Nominal sentence in Arabic language has some unique patterns in the headline news of Arabic daily newspapers in Egypt. Nominal sentences in Arabic language also had been divided into the information construction, theme and rheme. For in example, the nominal sentence which appeared in the book of al-Qira'ah ar-Rasyidah below.

Wa al-masjidu qaribun min al-baiti

"The mosque is near my home". 
From this sentence, we can find the theme and rheme in Arabic nominal sentence. The author will give information to the reader that the mosque (theme) is near the home (rheme). The data in this research also was taken from the book of Bidayah al-Hidayah written by Imam al-Ghazali. In this case, the purpose of this article is to develop the SFL theory in the Arabic-Javanese translation process and product in the translation book of moral ethic of Bidayah al-Hidayah.

Bidayah al-Hidayah (ath-thariq al-ubudiyyah) or "the way of slavery to the God" is the famous book of moral ethic in the Islamic students at traditional boarding school in Indonesia. This book was written by Imam al-Ghazali. This book had been translated into another language, such as in Javanese language. Kyai Haji Hammam Nashirudin from Magelang, Central Java, Indonesia, was the translator of that book into Javanese language. There are several chapters about moral ethic in this book, such as: (1) preface of the book about how the etiquette of learning; (2) the obedience toward Allah swt.; (3) the moral/ethics/adab to wake up from sleeping; (4) the moral/ethics entering the toilet or bathroom; (5) the moral/ ethics for doing wudhu' (cleanness); (6) the moral/ethics for taking a bath; (7) the moral/ethics for doing tayammum; (7) the moral/ethics for going out from the mosque, and so on about the moral/ethics in daily life based on Islamic ethics. By looking the pattern of delivering the message in every single chapter, the author of the book had been used the constant pattern. This constant pattern in delivering the Islamic message becomes the main reason selecting Bidayah al-Hidayah as a main data in this research.

The previous research related with Theme and Rheme construction had been elaborated by Sajarwa (2000). This research had elaborated about the construction of theme and rheme in a French language. This research elaborated 
comprehensively about the structural construction of theme and rheme. ${ }^{5}$ In Arabic language, Raof (2007) had made distinction between Theme, Subject, and Agent. ${ }^{6}$ Almanna (2016) had been focused in the translation of theme and rheme from Arabic language into English language. This research also had been focused in the annotating aspect of thematic progression in Arabic language. ${ }^{7}$ Anis (2016) emphasized his research about thematic progression in Arabic language using the main data from the book of Al-Qira'ah Rasyidah. The data had been collected from the writing skill of the students at MAN Karanganyar. ${ }^{8}$

\section{B. Discussion}

\section{Methods}

The data in this research was taken from the book of al-Qira'ah ar-Rasyidab and the Arabic-Javanese translation of Bidayah al-Hidayah written by the famous Islamic scholar, Imam al-Ghazali. The method in this research was divided into three parts: (a) collecting the data from the book of Bidayah al-Hidayah, the data is the clauses with nominal and verbal initial; (b) analysis data, using the descriptive analysis; (c) reporting the data. The data of the research is clauses with verbal and non-verbal predicate in the Arabic-Javanese translation book, Bidayah al-Hidayah. The reason for choosing this object material is a collaborative cultural translation

${ }^{5}$ Sajarwa, "Laporan Penelitian Konstruksi Tema Rema dalam Bahasa Prancis: Sebuah Penelitian Awal”, Fakultas Sastra Universitas Gadjah Mada Yogyakarta, 2000.

${ }^{6}$ Hussein Abdul Raof, Subject, Theme, and Agent in Modern Standard Arabic (London: Routledge, 2007).

${ }^{7}$ Ali Almanna, The Routledge Course in Translation Annotation (ArabicEnglish-Arabic) (New York: Routledge, 2016).

${ }^{8}$ Muhammad Yunus Anis, "Pengembangan Tema dalam Buku alQira'ah ar-Rasyidah Sebagai Pondasi Awal dalam Latihan Menulis Kreatif Bahasa Arab", Jurnal Arabiyat, Volume 2, Number 2, December 2015. 
which had been found from Bidayah al-Hidayah. There is some uniquely synthesis between Arabic and Javanese translation model of thematic progression pattern in that book. And also the book is very famous in the Islamic tradition students (santri) in Indonesia. Many Islamic traditional students in Indonesia have to read that book in the first class/level during their study as an introduction of Islamic law and sufism. The method used in this research is distribution analysis (metode Agih) with divided elements directly (bagi unsur langsung) to know the given and new information, the thematic progression, and the cohesive ties in the text of Bidayah alHidayah written by Imam al-Ghazali. From the analysis, we will find how Imam al-Ghazali delivers the Islamic message of moral ethic into the readers.

\section{Results and Discussion}

The linguists belonging to the Prague School saw an essential feature of language system but also the relations of language systems and language utterances to extralingual reality. ${ }^{9}$ Functional sentence perspective (perspective fonctionnelle de la phrase) besides word order language has other, non-linear means as its disposal which enable both the speaker and the hearer to distinguish between thematic and rhematic elements.

One of such non-linear means of functional sentence perspective in Modern English may be the non-generic signalizes a new element, (and sometimes) even the rheme proper. The definite article which has the capacity to refer to know entities may in turn signalize the theme. ${ }^{10}$ We can see

${ }^{9}$ Abul Chasan 'Aiy al-Chasaniy, al-Qira'ah ar-Rasyidah li Ta'lim alLughah al-Arabiyyah wa ats-Tsaqafah al-Islamiyyah (United Kingdom: UK Islamic Academy, 2003), 83.

${ }^{10}$ Ibid., 82. 
this case, in $\mathrm{QR}$, for example in this short poem about the time (as-sa'ab) below.

Al-waqtu wasi'un

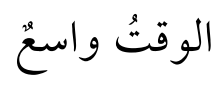

"The time is extensive". ${ }^{11}$

From the word al-waqtu we can describe that there is a definite article alif lam which has the capacity to refer to know entities may in turn signalize the theme in the non-verbal predicate sentence. Al-waqtu is the basis (starting point) of an utterance from the point of view functional sentence. And it is "given" or "known" information between the speaker and the hearer. And the nucleus of the sentence is 'wāsi'un', what the speaker says about the base. To understand well this example, we can see this table 1 below.

Table 1. Theme and Rheme in The Non-Verbal

Predicate Sentence

\begin{tabular}{cc}
\hline Al-waqtu & Wasi'un \\
\hline Subject & Predicate-non verbal \\
\hline Theme & Rheme \\
\hline Given or known information & New information \\
\hline
\end{tabular}

By using the functional grammar analysis, we can find from this research, two main paradigms of text as a massage and text as a source and target text of translation process. In every single text of Arabic and Javanese language, we will find the notion of theme and rheme. Theme is usually associated with the given element in a sentence, that is, the element which shared between reader and writer, while rheme contains new and focal elements. It is therefore natural in analysing text to assume that theme part of a sentence is

\footnotetext{
${ }^{11}$ Ibid., 23.
} 
related to something that has already been established, whereas the rheme part is the most likely location for what takes the text in new directions. ${ }^{12}$ If we look at the translation book of Bidayah al-Hidayah from Arabic (ST) into Javanese (TL) language, we will consider some pattern of them and rheme in the text, they are the dominant one, such as: (a) theme using the definitive marker (al) $+/ \mathrm{u} /$; (b) theme using the imperative verb; (c) theme in the headline of every chapter; and (d) theme inside the conditional sentences. We can also look at the construction of theme and rheme in the verbal predicate sentence. This model was found with the great number in the QR. Especially in an independent clause. An independent clause is a clause that can stand alone. Given and New information is found in both dependent and independent clauses and in combination of the two.

In order for a person to understand what the speaker is talking about. In order to communicate effectively, the speaker must bring to the hearer's attention some element of shared or "mutual knowledge". This shared information is usually found at the beginning of a clause and is labelled Given information. Most clauses also include information that is the focus of the speaker's message, information that is considered New. The two elements together make up an information unit. ${ }^{13}$ Thus, if a writer or speaker expects the interlocutor to know how he or she is doing his/her daily activities, "kaifa aqdliy yaumiy", first, the writer tells about his morning activities describing how he was sleeping at night and how is getting up in the early morning.

${ }^{12}$ Anna Mauranen, "Theme and Prospection in Written Discourse", in Mona Baker, et al. (eds.), Text and Technology in Honour of John Sinclair, (Amsterdam: John Benjamins Publishing Company, 1993), 95.

${ }^{13}$ Ibid. 


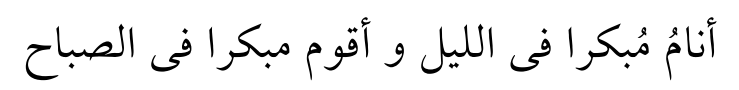

Anamu mubakkiran fi al-laili wa aqumu mubakkiran $f i$ ash-shababi.

I am sleeping early in the night and I am waking up in the early morning. ${ }^{14}$

The writer is making assumption that the interlocutor knows who is the subject of the verb "anamu", the subject is "ana" (I), and more particularly "anamu" can identify the particular verb "anamu" referred to. That is to say that they share the knowledge about the verb "anamu", and this knowledge is taken for granted in the statement. The main focus of the information (the new element) is "mubakkiran fi al-laili" (early in the night), which is found at the end of the clause. The information unit is also found in the sentence with the verbal predicate in the conversation between two persons below, Khalid and Umar.

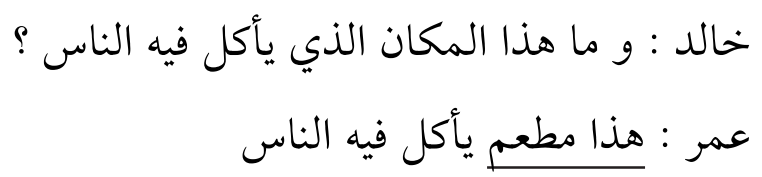

Khalid : Wa ma hadza al-makanu alladzi ya'kulu fibi an-nasu?

Umar : Hadza math'amun ya'kulu fibi an-nasu.

Khalid : What is a place where is people eating inside it?

Umar : This is a kitchen, a people eats there. ${ }^{15}$

Umar has informed to Khalid that "math'am" (kitchen) is the place where people can eat. From the phrase "hadza math'amun", we can analyze that there is demonstrative pronoun "hadza" (this). This phrase has the capacity to refer to know entities may in turn signalize the theme in the verbal

${ }^{14}$ Abul Chasan 'Aiy al-Chasaniy, al-Qira'ah ar-Rasyidah li Ta'lim al-Lughah al-Arabiyyah wa ats-Tsaqafah al-Islamiyyah, 14.

${ }^{15}$ Ibid., 22. 
predicate sentence "ya'kulu fihi an-nasu". Theme in this sentence is "hadza math'amun" and the rheme is "ya'kulu fihi an-nasu". In this conversation below, we can see that Umar said to inform the new information that stationer shop is the place to get many school requirements.

$$
\text { عمر: هذا دكانُ ورّاق تجد فيه جميع حوائج المدرسة }
$$

Umar: Hadza dukkanu warraqin tajidu fibi jami'u hawa'iji al-madrasah. Umar: This is a stationer shop, you can get there many school requirements. ${ }^{16}$

From the phrase "hadza dukkanu warraqin", we can conclude that the phrase is theme of verbal predicate "tajidu fihi jami'u hawa'iji al-madrasah". To understand clearly this case, we can look at the table 2 below.

Table 2. Theme and Rheme in The Verbal

Predicate Sentence

\begin{tabular}{cc}
\hline Hadza math'amun & Ya'kulu fihi an-nasu \\
\hline Subject & Predicate-verbal-ya'kulu \\
\hline Theme & Rheme \\
\hline Mubtada' & Khabar \\
\hline Given or known information & New information \\
\hline
\end{tabular}

So that, theme of a sentence (theme de la phrase) is the basis (starting point) of an utterance from the point of view functional sentence perspective. And rheme of a sentence (rheme de la phrase) is the core (focus) of an utterance from the point of view of functional sentence perspective.

The principal elements of the functional sentence perspective are the base of the utterance (theme), i.e. what is known or at least obvious in the given situation and from which the speaker departs, and the nucleus of the the utterance (rheme), i.e. what the speaker says about the base

${ }^{16}$ Ibid. 
or with respect to the base. We can call this concept with "the actual division of the sentence" (division actuelle de la phrase).

By using the functional grammar analysis, we can find from this research, two main paradigms of text as a massage and text as a source and target text of translation process. In every single text of Arabic and Javanese language, we will find the notion of theme and rheme. Theme is usually associated with the given element in a sentence, that is, the element which shared between reader and writer, while rheme contains new and focal elements. It is therefore natural in analysing text to assume that theme part of a sentence is related to something that has already been established, whereas the rheme part is the most likely location for what takes the text in new directions. ${ }^{17}$ If we look at the translation book of Bidayah al-Hidayah from Arabic (ST) into Javanese (TL) language, we will consider some pattern of them and rheme in the text, they are the dominant one, such as: (a) theme using the definitive marker (al) $+/ \mathrm{u} /$; (b) theme using the imperative verb; (c) theme in the headline of every chapter; and (d) theme inside the conditional sentences.

\section{a. Theme using the definitive marker $(\mathrm{al})+/ \mathrm{u} /$}

\begin{tabular}{ll}
\hline \multicolumn{1}{c}{ Theme } & \multicolumn{1}{c}{ Rheme } \\
\hline (1) Al-chamdu & lillähi \\
\hline Utawi sekabehane puji & Iku kagungane Allah ${ }^{18}$ \\
\hline \multicolumn{2}{c}{ Praise be to God!! } \\
\hline
\end{tabular}

Figure 1: Model of Theme using definitive marker

${ }^{17}$ Anna Mauranen, "Theme and Prospection in Written Discourse", in Mona Baker, et al. (eds.), Text and Technology in Honour of John Sinclair, (Amsterdam: John Benjamins Publishing Company, 1993), 95.

${ }^{18}$ Hammam Nashiruddin, Bidayah al-Hidayah, (Kudus: Maktabah Manara, 1964), 8. 
By looking the example in the figure 1, the theme in Arabic language had been marked by the definitive marker (al) + vocal /u/. For example the word al-chamdu (1) was translated into Javanese language using the marker (1a) utawi sekabebane puji. Thus, the translation marker for theme in Arabic-Javanese translation can be formulated by $((\mathrm{al})+/ \mathrm{u} /$ $=$ utawi .... ). The word al-chamdu occupied in the position of theme and mubtada'. The phrase lillāhi had been determined as rheme and khabar. The word "subject" in Arabic language had the same meaning with the term / fái il/ or / musnad/, the word Theme in SFL can be defined as maudhü. ${ }^{19}$

The Difference between Subject, Actor, Agent, and Theme

\begin{tabular}{|c|c|c|c|c|}
\hline & $\begin{array}{l}\text { Mahmoud } \\
\text { (2010) }\end{array}$ & $\begin{array}{c}\text { Baalbaki } \\
(1990)\end{array}$ & $\begin{array}{l}\text { Al-Khuli } \\
\text { (1982) }\end{array}$ & $\begin{array}{l}\text { Richards in the } \\
\text { Longman }\end{array}$ \\
\hline Subject & $\begin{array}{c}\text { Musnadl } \\
\overline{f a} \text { ill }\end{array}$ & $\begin{array}{l}\text { Musnad } \\
\text { ilaib/ } \\
\text { mubtada' }\end{array}$ & $\begin{array}{l}\text { Musnad } \\
\text { ilaih/ } \\
\text { mubtada' }\end{array}$ & $\begin{array}{c}\text { Musnad ilaib/ } \\
\text { mubtada' }\end{array}$ \\
\hline Actor & Fa'il & $\begin{array}{c}\text { Fa'ilun } \\
\text { chaquiqiyyun }\end{array}$ & $\begin{array}{c}\text { Fa'ilun } \\
\text { chäiqiaiyyn }\end{array}$ & - \\
\hline Agent & $\begin{array}{c}\text { Musnadl } \\
\overline{f a} \text { íl }\end{array}$ & $\begin{array}{l}\text { Qa'im bil- } \\
\text { filli }\end{array}$ & $\begin{array}{c}\overline{F a} \text { il } \\
\text { chagiqiyyun }\end{array}$ & Fa'ilul-chadats \\
\hline Theme & $\begin{array}{l}\text { Maudh"̄' } \\
\text { madhmūn }\end{array}$ & Maudh"̄' & Maudh"̄' & Maudh $\bar{u}^{\prime}$ \\
\hline
\end{tabular}

\section{b. Theme using the imperative verb}

\begin{tabular}{ll}
\multicolumn{1}{c}{ Theme } & \multicolumn{1}{c}{ Rheme } \\
\hline (2) Ighsil & Yadaika tsalätsan \\
(3) wa qul & $\begin{array}{l}\text { Allabuma inni as'aluka al-yumna wal } \\
\text { barakata }\end{array}$ \\
\hline (2a) masubo siro & Ing tangan loro iro ${ }^{20}$ \\
\hline
\end{tabular}

${ }^{19}$ Mohamed Mahmoud, Dictionary of Literary and Linguistic Terms English-Arabic (Mesir: ad-Dar al-Mishriyyah li al-Kitab, 2010), 165.

${ }^{20}$ Hammam Nashiruddin, Bidayah al-Hidayah, (Kudus: Maktabah Manara, 1964), 58. 


\begin{tabular}{ll}
\hline & Ya Allah setubune kula - nyumun kula ing \\
(3a) lan ngucapa siro & Tuban - ing qiyat tha'at lan ing tambabe \\
& kebagusan
\end{tabular}

Figure 2: Model of Theme using the imperative verb

By elaborating the figure 2, the theme in Arabic language is the imperative verb, such as /ighsil/ "you have to wash!" and /qul/ "you have to speak". The theme in Arabic language was translated by shifting translation from word into phrase, from the imperative verb into phrase, for example from the verb /ighsil/ (اغسل) into phrase "masubo siro" (V+S) and the word /qul/ (قل) "ngucapo siro". Thus, we can conclude that there is a theme using the imperative verb in Arabic language, and the translation of theme was the shifting translation from word into phrase.

c. Theme in the headline of every chapter in the Bidayah al-Hidayah

\begin{tabular}{ll}
\hline \multicolumn{1}{c}{ Theme } & \multicolumn{1}{c}{ Rheme } \\
\hline (4) al-qismu al-awwalu & Fith-thààt \\
\hline (5) fashlun & Fi ädäbil-istaiqädzi minan-naumi \\
\hline
\end{tabular}

\begin{tabular}{ll}
\hline $\begin{array}{l}\text { (4a) utawi dunduman } \\
\text { kang awwal }\end{array}$ & $\begin{array}{l}\text { Iku ing dalem bicaraake piro-piro } \\
\text { tha'at }\end{array}$ \\
\hline $\begin{array}{l}\text { (5a) utawi iki fashal } \\
\text { suwiji }\end{array}$ & $\begin{array}{l}\text { Ing dalem mertelaaken totokromone } \\
\text { tangi saking turu }\end{array}$ \\
\hline
\end{tabular}

Figure 3: Model of Theme in the headline of every chapter in the Bidayah al-Hidayah

By looking the figure 3, we can conclude that there is a theme in Arabic language had been taken from the title of the chapter (headline), for example (4) al-qismu al-awwalu "part

${ }^{21}$ Ibid., 33.

${ }^{22}$ Ibid., 79. 
one" is the starting point of the text and also (5) fashlun "the part" is a theme in Arabic language and both of theme had been translated into Arabic theme using the marker "utaw?". The pattern marker of the headline in Javanese language (utawi + ing dalem).

\section{d. Theme inside the conditional sentences in the book of Bidayah al-Hidayah}

\begin{tabular}{cccc}
\hline Theme 1 & Rheme 1 & Theme 2 & Rheme 2 \\
\hline (6) $\underline{\text { Fa idza }}$ Min an-naumi & $\begin{array}{l}\text { Fajtabid } \\
\text { istaiqadzta }\end{array}$ & $\begin{array}{l}\text { An tastaiqidza } \\
\text { (imperative verb) } \\
\text { qabla thulu' } \\
\text { al-fajri }^{1}\end{array}$
\end{tabular}

\begin{tabular}{|c|c|c|c|}
\hline $\begin{array}{l}\text { (6a) Mongko } \\
\text { tatkalane } \\
\text { amrih tangi } \\
\text { siro }\end{array}$ & Saking turu & $\begin{array}{l}\text { Mangka nemen- } \\
\text { nemen nane siro }\end{array}$ & $\begin{array}{l}\text { Ing yento-tangi } \\
\text { siro-ing } \\
\text { sakdurungue- } \\
\text { metune fajar }\end{array}$ \\
\hline $\begin{array}{l}\text { (7) Fain } \\
\text { 'ajazta }\end{array}$ & $\begin{array}{l}\text { 'An isti'mali } \\
\text { al-ma'i }\end{array}$ & $\begin{array}{l}\text { Fashbir } \\
\text { (imperative verb) }\end{array}$ & $\begin{array}{l}\text { Hatta } \\
\text { yadkhula waqt } \\
\text { al-faridhati }\end{array}$ \\
\hline
\end{tabular}

\begin{tabular}{llll}
\hline (7a) Maka & Sangking & Mangka sabara & Sabingga \\
lamun-apes & nganggo-banyu & siro & manjing apa \\
siro & & & weqtune shalat \\
& & & fardhu $^{2}$ \\
\hline
\end{tabular}

Figure 4: Model of Theme inside the conditional sentences in the book of Bidayah al-Hidayah

From figure 4, we can conclude that there is a multiple or double theme in Arabic language, (theme 1) and (theme 2). The marker of theme 1 is the word / fa/ in Arabic language "then or so". The marker of the theme 2 is imperative verb

\footnotetext{
${ }^{23}$ Ibid., 41.

${ }^{24}$ Ibid., 84.
} 
in Arabic language. Both of them had been translated into Javanese language by the marker "mangka".

\section{Conclusion}

This research has tried to make the case that texts in the book of al-Qira'ah ar-Rasyidab have texture as a result of a complex interaction of linguistic resources which are used by writers and speakers to construct coherence. This resources include the information structure (organization of given and new information) and the thematic structure (theme and rheme) at clause level and also the way in which thematic patterns (thematic progression) are built up from clause to clause through a text. The thematic sturtures of the text is supported by the cohesive component of the grammar, which consists of reference, ellipsis, and substitution, conjunction and lexical cohesion. Although we may analyze each of these elements separately, there is likely to be a blending of many cohesive elements in any stretch of genuine discourse except in very short or abbreviated texts. The result of analysis theme and rheme construction in the book of al-Qira'ah ar-Rasyidah shows that both of theme and rheme were found in the sentences with verbal predicate and non-verbal predicate.

The data of this research is some moral ethic books, such as Bidayah al-Hidayah (BDH). This book is a translation book from Arabic into Javanese language. The data of this research also was taken from the book of al-Qira'ah arRasyidah (QR). This book was included the simple poetry and short story about the Islamic morality. Language typology being concerned with universal laws and patterns, began with the study of the relative order of sentence constituents verb $(\mathrm{V})$, subject $(\mathrm{S})$, and object $(\mathrm{O})$, arranged into permutations of SVO, VSO, and others. This taxonomy has been adopted 
by some Arabists as a construc within whihc Arabic may be situated. There are two types of sentences group in this research, nominal and verbal sentences. The pattern of nominal sentence is $\mathrm{S}+\mathrm{V}+\mathrm{O}$ and the pattern of verbal sentence is $\mathrm{V}+\mathrm{S}+\mathrm{O}$. After doing the analysis of the data, using the functional grammar approach, we can conclude about the form of the theme and rheme in the translation text of Islamic moral ethic book Bidayah al-Hidayah. First, there are four dominant pattern in the construction themerheme pattern inside the Islamic moral ethic book, (1) theme using definitive marker (al) $+/ \mathrm{u} /$; (2) theme using the imperative verb; (3) theme in the headline of every chapter in the book of Bidayah al-Hidayab; and (4) theme in the conditional sentences. 


\section{REFERENCES}

Almanna, Ali. The Routledge Course in Translation Annotation (Arabic-English-Arabic). New York: Routledge, 2016.

Anis, Muhammad Yunus. "Strategi Penerjemahan ArabJawa Sebagai Sebuah Upaya dalam Menjaga Kearifan Bahasa Lokal (Indigenous Language): Studi Kasus dalam Penerjemahan Kitab Bidayah al-Hidayah Karya Imam al-Ghazali", Jurnal Akademika, Vol. 21, No. 1, JanuariJuni 2016.

"Pengembangan Tema dalam Buku al-Qira'ah arRasyidah Sebagai Pondasi Awal dalam Latihan Menulis Kreatif Bahasa Arab”, Jurnal Arabiyat, Vol. 2, No. 2, Desember 2015.

. "Konstruksi Tema Rema Judul Berita dalam Surat

Kabar al-Abram: Analisis Sintaksis", Lisania Jurnal Ilmu dan Pendidikan Bahasa Arab, Vol. 5, No. 2, 2014.

Anis, Muhammad Yunus, Arifuddin, dan Eva Farhah. Panduan Menulis Kreatif Bahasa Arab: Pengembangan Tema dalam Buku al-Qira'ah ar-Rasyidah. Surakarta: Program Studi Sastra Arab UNS, 2015.

al-Chasaniy, Abul Chasan 'Aiy. Al-Qira'ah ar-Rasyidab li Ta'lim al-Lugah al-'Arabiyyah wa ats-Tsaqafah al-Islamiyyah. United Kingdom: UK Islamic Academy, 2003.

Mauranen, Anna. "Theme and Prospection in Written Discourse", in Mona Baker, et al. (eds.). Text and Technology in Honour of John Sinclair. Amsterdam: John Benjamins Publishing Company, 1993.

Nashiruddin, Hammam. Bidayah al-Hidayah. Kudus: Maktabah Manara, 1964. 
Raof, Hussein Abdul. Subject, Theme, and Agent in Modern Standard Arabic. London: Routledge, 2007.

Sajarwa. "Laporan Penelitian Konstruksi Tema Rema dalam Bahasa Prancis: Sebuah Penelitian Awal”. Yogyakarta: Fakultas Sastra Universitas Gadjah Mada, 2000.

Versteegh, Kees (ed.). Encyclopedia of Arabic Language and Linguistics. Leiden: Brill, 2006. 